\title{
Erratum to: Tricuspid Valve Surgery in Patients with Isolated Tricuspid Valve Endocarditis: Analysis of Perioperative Parameters and Long- Term Outcomes. Thorac Cardiovasc Surg 2015 [efirst ahead of print]
}

Bettina Pfannmueller ${ }^{1 *}$ Mareike Kahmann ${ }^{1 *}$ Piroze Davierwala $^{1} \quad$ Martin Misfeld $^{1} \quad$ Farhad Bakhtiary $^{1}$ Christian Binner ${ }^{1}$ Christian Etz ${ }^{1}$ Friedrich Wilhelm Mohr ${ }^{1}$

\footnotetext{
${ }^{1}$ Department of Heart Surgery, Leipzig Heart Centre, University of Leipzig, Leipzig, Germany,

Address for correspondence Bettina Pfannmueller, MD, PhD, Heart Surgery, Heart Centre Leipzig, Strümpellstr. 39, Leipzig 04289, Germany (e-mail: bettina.pfannmueller@medizin.uni-leipzig.de).
}

*Both authors contributed equally to this work

Thorac Cardiovasc Surg 2017;65:e1.

ERRATUM

received

October 30, 2015

accepted after revision

October 31, 2015
It has been brought to the Editor-in-Chief's attention that the author list of this article is incomplete as published eFirst on October 26, 2015. DOI of the original article is DOI: $10.1055 / \mathrm{s}-0035-1564926$.

Author name Prof. Friedrich Wilhelm Mohr has been added. The correct list of authors is as above.

Editor-in-Chief Markus K. Heinemann

(C) 2017 Georg Thieme Verlag KG Stuttgart · New York
DOI https://doi.org/ $10.1055 / \mathrm{s}-0035-1568864$. ISSN $0171-6425$. 